\title{
Peran orang tua sebagai fasilitator anak dalam proses pembelajaran online di rumah
}

\author{
${ }^{1}$ Ria Nur Anggraeni, ${ }^{2}$ Fina Fakhriyah, ${ }^{3}$ Muhammad Noor Ahsin \\ 1riaa99460@gmail.com \\ 1,2 Pendidikan Guru Sekolah Dasar, Fakultas Keguruan dan Ilmu Pendidikan, \\ Universitas Muria Kudus \\ ${ }^{3}$ Pendidikan Bahasa dan Sastra Indonesia, Fakultas Keguruan dan Ilmu Pendidikan, \\ Universitas Muria Kudus
}

\begin{abstract}
ABSTRAK
Penelitian ini bertujuan untuk menganalisis peran orang tua sebagai fasilitator pembelajaran online juga kendala orang tua sebagai fasilitator. Peneilitian ini berjenis kualitatif deskriptif dengan teknik pengumpulan data yang digunakan adalah melalui observasi, wawancara, angket, dan dokumentasi. Analisis data yang digunakan dalam penelitian ini adalah reduksi data, penyajian data dan verifikasi. Adapun hasil penelitian yakni peran orang tua sebagai fasilitator dalam pembelajaran online berupa sebagai pembimbing, jembatan antara guru dan anak, serta penyedia fasilitas-fasilitas yang menunjang. Selain itu dalam pelaksanaannya juga terdapat beberapa kendala diantaranya kurangnya pemahaman materi pembelajaran oleh orang tua dan motivasi anak yang cenderung menurun. Sehingga dalam pelaksanaannya orang tua mencoba mencari beberapa sumber yang bisa membantu menambah pemahaman dan memberikan motivasi kepada anak.
\end{abstract}

Kata Kunci: fasilitator, peran orang tua, pembelajaran online

\section{The role of parents as child facilitators in the online learning process at home}

\begin{abstract}
This study aimed to analyze the role of parents as facilitators of online learning as well as the constraints of parents as facilitators. This research was descriptive qualitative research with data collection techniques used through observation, interviews, questionnaires, and documentation. Data analysis used in this research was data reduction, data presentation, and verification. The results of the research were parents as facilitators in online learning in the form of mentors, bridges between teachers and children, and providers of supporting facilities. In addition, in its implementation, there were also several obstacles, including a lack of understanding of learning materials by parents and children's motivation which tends to decline. So that, parents tried to find several sources that could help increase understanding and provide motivation to children.
\end{abstract}

Keywords: facilitator, the role of parents, online learning 


\section{PENDAHULUAN}

Pandemi COVID 19 tengah melanda negara di seluruh dunia. Negara Indonesia juga sedang berjuang menghadapi pandemic COVID 19 ini. Hal ini dilakukan dengan terjadinya beberapa perubahan kebijakan. Beberapa perubahan tersebut mencakup dalam semua aspek kehidupan mulai dari aspek ekonomi, pendidikan, sodial, keagaman, budaya, dan lainnya. Khususnya dalam pendidikan yang sangatlah terasa perubahan-perubahannya. Pendidikan merupakan hal yang harus diterima masyarakat meskipun dalam keadaan pandemi ini. Sebab pendidikan merupakan upaya terencana yang berlangsung secara kontinyu sepanjang hidup untuk membimbing anak menjadi manusia yang dewasa, berbudaya, dan paripurna (Susanto, 2013). Pendidikan pada masa sebelum pandemi dengan metode tatap muka dan dilaksanakan pada ruangan tertentu secara berkumpul. Sedangkan pada masa pandemi ini pembelajaran dilaksanakan secara online atau dalam jaringan dengan teknologi yang terhubung dengan internet (Sholeh, Murtono, Masfuah, 2021). Pembelajaran harus dilaksanakan di rumah. Hal ini dilakukan guna memutus rantai penyebaran virus Covid-19.

Pembelajaran online merupakan pembelajaran jarak jauh antara guru dan siswa yang memanfaatkan media elektronik berupa teknologi, informasi, dan komunikasi (Winarno \& Setiawan, 2013). Pembelajaran online memiliki beberapa karakteristik diantaranya pengajar dan siswa berada di tempat yang terpisah, antar siswa juga berada pada tempat yang terpisah pada pelaksanaan pembelajaran, pembelajaran memanfaatkan sarana teknologi, komunikasi, maupun informasi (Warsito, 2012). Hal ini juga sesuai dengan bahwa dalam pembelajaran online siswa dituntut untuk mamahami materi tanpa interaksi langsung dengan guru serta materi yang disampaikan guru tidak maksimal tua (Syafa'ati et al., 2021). Oleh karena itu, dalam pembelajaran online, siswa dapat mencapai tujuan pembelajaran meskipun dengan metode pembelajaran yang cenderung baru.

Peran guru dalam pembelajaran online menjadi tergeser. Orang tua mempunyai peran penting bagi terwujudnya hasil belajar yang optimal (Wardhani \& Krisnani, 2020). Peran orang tua dalam mendukung keberhasilan pembelajaran anak mencapai tujuan meliputi orang tua sebagai pengasuh dan pendidik untuk melatih pengetahuan, keterampilan dan mental anak, peran yang lain sebagai pembimbing dengan membantu menyelesaikan kesulitan anak. Selain itu orang tua juga sebagai motivator dengan memberikan dorongan kepada anak tentang pentingnya belajar, serta orang tua menjadi fasilitator berupa menyediakan 
berbagai fasilitas yang mendukung.

Fokusnya dalam hal ini yakni fasilitator. Orang tua sebagai fasilitator yakni dengan menyediakan fasilitas belajar yang dibutuhkan juga hal-hal yang dapat meningkatkan prestasi belajar anak (Kholiq et al., 2017). Hal ini menandakan bahwa orang tua sebagai fasilitator merupakan sebagai penyedia. Sebagaimana guru yang menyediakan bahan ajar maka orang tua juga sebagai penyedia hal-hal yang dibutuhkan dalam pembelajaran online. Beberapa hal yang dibutuhkan yakni media elektronik, kuota, tempat belajar yang nyaman, dan fasilitas lain yang menunjang kegiatan pembelajaran online. Jika anak tidak mendapatkan fasilitas tersebut yang terjadi yakni anak tidak bisa mengikuti pembelajaran online dengan efektif (Umar, 2015).

Orang tua sebagai fasilitator dalam pembelajaran anak meliputi beberapa tugas yakni menyediakan fasilitas belajar baik berupa tempat belajar, alat tulis, buku-buku pelajaran, dan lain-lain yang dapat memudahkan proses belajar siswa (Prasetyo, 2018). Selain itu orang tua harus mengawasi kegiatan belajar anak di rumah sehingga dapat mengetahui perkembangan belajar anak. Selain itu, dengan pengawasan orang tua diharapkan anak lrbih disiplin dalam belajar. Orang tua juga berperan untuk mengawasi penggunaan waktu belajar anak dengan membantu menyusun jadwal. Peran lainnya sebagai fasilitator berupa orang tua mengatasi kesulitan belajar anak.

Sebelum melakukan penelitian, peneliti melakukan observasi awal tentang peran orang tua sebagai fasilitator anak dalam proses pembelajaran online di rumah. Observasi awal dilaksanakan di desa Sidokerto Kecamatan Pati Kabupaten Pati pada Sabtu, 29 Agustus 2020. Observasi awal dilaksanakan pada Desa Sidokerto Kecamatan Pati Kabupaten Pati diketahui pembelajaran online di sekolah dasar di desa Sidokerto Kecamatan Pati Kabupaten Pati kebanyakan dilaksanakan secara online. Sehingga berdasarkan uraian tersebut peneliti tertarik melakukan penelitian dengan fokus peran orang tua sebagai fasilitator dalam pembelajaran online.

Pelaksanaan pembelajaran tersebut dibantu dengan platform pembelajaran seperti Whatsapp Group (WAG), Zoom, maupun YouTube. Dalam pembelajaran tersebut banyak guru memberikan tugas. Dalam mengerjakan tugas perlu didampingi orang tua siswa. Kebanyakan pendampingan orang tua dalam mengerjakan tugas dan pendampingan pembelajaran dilaksanakan dalam waktu 
malam hari. Kendala tersebut meliputi orang tua yang merasa keberatan dalam pembelian kuota. Hal tersebut sesuai dengan hasil wawancara oleh orang tua SN bahwa pembelajaran online lebih membutuhkan banyak uang untuk membeli data internet. Juga disebut oleh orang tua lain HR bahwa dalam penyediaan fasilitas kadang kesulitan karena keadaan ekonomi.

Penelitian terdahulu yang relevan tentang peran orang tua dengan judul pendampingan anak dalam keluarga di TK Pertiwi Kebasen Kabupaten Banyumas dan hasil penelitiannya adalah bahwa bentuk pendampingan dilakukan melalui keteladanan, peduli dan berbagi, kepercayaan, motivasi, kebersamaan, tanggung jawab dan memberikan penghargaan (Saputri, 2017). Berdasarkan uraian di atas, maka peneliti melakukan penelitian dengan judul peran orang tua sebagai fasilitator anak dalam proses pembelajaran online di rumah. Adapun tujuan penelitian ini yakni pertama, mendeskripsikan peran orang tua sebagai fasilitator anak saat pembelajaran online di rumah serta menjelaskan kendala yang dialami orang tua sebagai fasilitator dalam proses pembelajaran online di rumah.

\section{METODE PENELITIAN}

Jenis penelitian ini merupakan penelitian kualitatif dengan pendekatan deskriptif. Penelitian ini dilaksanakan untuk menggambarkan serta menganalisis suatu hasil penelitian. Pelaksanaan penelitian ini dilakukan di Desa Sidokerto Kecamatan Pati Kabupaten Pati. Pemilihan tempat penelitian tersebut didasari oleh beragamnya jenis sekolah yang ada di desa tersebut. Mulai dari sekolah dasar negeri hingga Sekolah Dasar Islam Terpadu (SDIT). Penelitian dilaksanakan selama satu bulan yakni pada bulan Januari hingga Februari 2021. Pengambilan data dilakukan oleh peneliti sebagai instrumen utama.

Adapun subjek penelitiannya merupakan tujuh orang tua anak dan tujuh anak usia sekolah dasar. Subjek tersebut merupakan warga desa Sidokerto yang mempunyai latar belakang yang berbeda khususnya pekerjaan orang tua. Sedangkan untuk subjek anak usia sekolah dasar merupakan siswa kelas rendah dan siswa kelas tinggi. Pengambilan subjek tersebut dengan cara purposive sampling. Tujuan pengambilan subjek terebut dikarenakan sekolah yang berbeda-beda dan latar belakang pekerjaan orang tua juga berbeda.

Teknik pengumpulan data tersebut dengan observasi, wawancara, dan angket yang dilakukan kepada orang tua anak beserta anak sebagai data pendukung. 
Observasi dilakukan secara langsung oleh peneliti. Peneliti melakukan pengamatan mengenai peran orang tua sebagai fasilitator anak dalam pembelajaran online di rumah. Adapun subjek yang dipilih peneliti yakni orang tua yang memiliki anak usia sekolah dasar yang sedang menempuh pembelajaran online dan anak usia sekolah dasar tersebut.

Teknik selanjutnya yakni Teknik wawancara. Adapun wawancara yang digunakan merupakan wawancara yang terstruktur. Kegiatan wawancara ini berupa tanya jawab kepada narasumber. Wawancara ini memilih narasumber orang tua dengan topik peran orang tua sebagai fasilitator pembelajaran online dan kendala orang tua sebagai fasilitator. Selain itu narasumber lain yakni anak usia sekolah dasar dengan topik wawancara mengenai pembelajaran online dan peran orang tua sebagai fasilitator pembelajaran online di rumah.

Kedua Teknik tersebut merupakan Teknik pengambilan yang utama. Selain data utama, peneliti juga memiliki data pendukung yang berupa hasil data angket. Angket ini berguna untuk menambah informasi dan menambah data. Angket ini merupakan angket tertutup yang ditujukan untuk orang tua. Topik angket ini tentang peran orang tua sebagai fasilitator pembelajaran online di rumah. Tujuan angket ini merupakan untuk mendapatkan tanggapan orang tua sebgaia fasilitator pembelajaran online.

Fokus pada penelitian ini mengenai peran orang tua fasilitator dalam pembelajaran daring. Tahap selanjutnya yakni analisis data. Adapun analisis data terdiri dari reduksi data, penyajian data, dan verifikasi data. Reduksi data berupa pemilihan dan penyerdehanaan pada poin-poin utama pada data yang telah dikumpulkan. Penyajian data berupa uraian singkat, maupun tabel yang bertujuan untuk memudahkan dalam memahami hasil. Kemudian tahap verifikasi berupa temuan berupa deskripsi atau gambaran suatu objek (Sugiyono, 2017).

\section{HASIL DAN PEMBAHASAN}

\section{Peran Orang Tua Sebagai Fasilitator Anak Saat Pembelajaran Online}

Pelaksanaan pembelajaran online berdasarkan hasil observasi diawali dengan anak mempersiapkan diri untuk belajar, guru mulai membuka pembelajaran dengan menanyakan kabar dan memberikan beberapa motivasi. Guru lalu memberikan beberapa materi pembelajaran melalui WAG dan Youtube. Selanjutnya, guru memberikan tugas yang harus diselesaikan anak dengan batas waktu yang ditentukan. Pembelajaran online yang dilaksanakan dalam keadaan jarak jauh 
sangat memanfaatkan kemjauan teknologi dan informasi. Hal ini diketahui kemajuan teknologi informasi bisa menghubungkan siswa dengan guru dengan pemanfaatan internet (Astini, 2020).

Pelaksanaan pembelajaran online di desa Sidokerto Kecamatan Pati Kabupaten Pati diketahui berdasarkan observasi bahwa proses pembelajaran dilakukan dengan beberapa tahap. Tahap pertama anak dibantu orang tua mempersiapkan diri untuk belajar. Tahap kedua, anak mulai melakukan kegiatan pembelajaran online melalui beberapa media pembelajaran yakni Whatsapp Group (WAG), Zoom, Google Form, Youtube, dan gambar-gambar yang berkaitan dengan materi. Tahap ketiga pengerjaan tugas oleh anak dengan bimbingan orang tua bagi siswa kelas rendah (kelas 1, 2, dan 3). Tugas-tugas tersebut berupa tugas tertulis dan praktik. Untuk kelas rendah fokusnya pada tugas menulis, membaca, dan berhitung. Sedangkan untuk kelas tinggi berupa penugasan, namun cenderung pada aspek pengetahuan. Untuk aspek sikap belum optimal penerapannya.

Dalam pelaksanaan pembelajaran online tersebut, berbagai macam peran yang telah dilakukan oleh orang tua mulai dari orang tua sebagai pendamping anak, pembimbing, dan penyedia fasilitas. Hal ini disebabkan terjadi pergeseran peran guru dan hanya orang tua yang mendampingi siswa selama pembelajaran daring (Khurriyati et al., 2021).

Berdasarkan wawancara dengan Narasumber ER yang merupakan orang tua anak kelas 2 mengenai bentuk pendampingan dalam pembelajaran online diketahui bahwa ER sekolah dasar mendampingi anak belajar dari awal pembelajaran hingga akhir pembelajaran. Selain itu ER juga mersepon tanggapan dari guru, serta yang mengirimkan tugas kepada guru. Dalam pelaksanaan pembelajaran online ER juga menyediakan beberapa fasilitas yang menunjang pembelajaran. Seperti tempat belajar yang nyaman, alat tulis, alat dan bahan yang diperlukan pada saat pembelajaran saat itu, handphone, dan wifi.

Berbeda dengan SN yang merupakan orang tua anak kelas 4 sekolah dasar yang melakukan pendampingan secara tidak langsung. Pendampingan tersebut berupa SN mengingatkan anaknya mengenai tugas pembelajaran. SN juga tidak melakukan pendampingan dari awal pembelajaran hingga akhir pembelajaran, sebab anaknya sudah bisa belajar secara mandiri dan mengumpulkan tugasnya sendiri. Guna menyukseskan pembelajaran online, SN juga menyediakan beberapa 
failitas berupa kuota, buku-buku, alat-alat tulis lainnya serta alat dan bahan yang dibutuhkan untuk menunjang materi. Seperti alat dan bahan yang dibutuhka pada saat pembelajaran kesenian atau membuat sesuatu.

Secara lebih jelas dan lengkap mengenai peran orang tua sebagai fasilitator dalam pembelajaran online disajikan dalam tabel berikut.

Tabel 1. Rekapitulasi data peran orang tua dalam pembelajaran online

\begin{tabular}{|c|c|}
\hline Orang Tua & Peran \\
\hline NN & $\begin{array}{l}\text { a. Mengawasi anak dalam ketika pembelajaran online } \\
\text { b. Mengingatkan anak untuk menyelesaikan tugas } \\
\text { c. Memberikan fasilitas berupa kouta, handphone, beberapa alat } \\
\text { tulis, dan hal-hal yang menunjang lainnya. }\end{array}$ \\
\hline ER & $\begin{array}{l}\text { a. Membimbing anak secara penuh dalam pembelajaran online } \\
\text { b. Mendampingi anak dalam menyelesaikan tugas } \\
\text { c. Membantu anak saat mengumpulkan tugas } \\
\text { d. Memberikan fasilitas berupa wifi, handphone, beberapa alat tulis, } \\
\text { dan hal-hal yang relevan dengan tugas }\end{array}$ \\
\hline SN & $\begin{array}{l}\text { a. Mengingatkan anak untuk menyelesaikan tugas tepat waktu } \\
\text { b. Mengawasi anak dalam pembelajaran online } \\
\text { c. Memberikan fasilitas berupa kuota, handphone, beberapa alat } \\
\text { tulis, dan hal-hal yang relvan dengan pembelajaran }\end{array}$ \\
\hline HT & $\begin{array}{l}\text { a. Mendampingi anak ketika pembelajaran online } \\
\text { b. Membantu anak dalam menyelesaikan kesulitan belajar } \\
\text { c. Memberikan fasilitas berupa tempat belajar yang nyaman, kuota, } \\
\text { handphone, beberapa alat tulis, dan hal-hal yang menunjang } \\
\text { pembelajaran }\end{array}$ \\
\hline YW & $\begin{array}{l}\text { a. Mendampingi anak secara penuh dalam pembelajaran online } \\
\text { b. Membimbing anak dalam menyelesaikan tugas. } \\
\text { c. Menjadi penghubung antara anak dan guru } \\
\text { d. Memberikan fasilitas berupa tempat belajar, kuota, handphone, } \\
\text { beberapa alat tulis, dan hal-hal yang menunjang pembelajaran }\end{array}$ \\
\hline AI & $\begin{array}{l}\text { a. Mendampingi anak dalam pembelajaran online } \\
\text { b. Memenuhi segala kebutuhan anak } \\
\text { c. Memberikan fasilitas berupa tempat belajar, kuota, beberapa alat } \\
\text { tulis, dan hal-hal yang menunjang pembelajaran }\end{array}$ \\
\hline YS & $\begin{array}{l}\text { a. Membimbing anak ketika pembelajaran online } \\
\text { b. Membantu anak ketika mendapat kesulitan mengerjakan tugas. } \\
\text { c. Memberikan fasilitas berupa tempat belajar, kuota, beberapa alat } \\
\text { tulis, dan hal-hal yang menunjang lainya }\end{array}$ \\
\hline
\end{tabular}

Berdasarkan tabel tersebut menunjukkan bahwa anak kelas rendah masih membutuhkan bimbingan orang tua secara penuh dalam melakukan pembelajaran online mulai awal pembelajaran hingga anak mengerjakan tugas. Berbeda dengan anak kelas tinggi. Pendampingan anak kelas tinggi tidak secara penuh. Hal ini disebabkan anak kelas tinggi sudah mulai mandiri dalam belajar. Pendampingan 
orang tua dilakukan pada saat-saat tertentu ketika anak tersebut membutuhkan. Meskipun demikian orang tua tetap mengawasi kegiatan belajar anak.

Orang tua sebagai fasilitator saat pembelajaran online bervariasi yakni orang tua sebagai pembimbing anak, orang tua sebagai jembatan antara anak dan guru, dan orang tua sebagai penyedia fasilitas pembelajaran. Peran orang tua sebagai pembimbing anak dilakukan secara langsung maupun tidak langsung. Bimbingan langsung dilaksanakan pada anak yang sedang berada pada kelas bawah. Hal ini dilakukan karena anak kelas rendah belum bisa mengoprasikan media teknologi dan informasi secara optimal dan tepat guna. Sebagaimana anak kelas I sampai III memerlukan bimbingan dari orang tua serta memberikan jadwal-jadwal belajar secara khusus (Dewi, 2020). Juga dikuatkan bahwa orang tua memiliki tanggung jawab utama dalam proses pertumbuhan dan perkembangan anak (Lilawati, 2020). Sehingga dalam hal ini termasuk bimbingan belajar anak oleh orang tua.

Sebagaimana hasil wawancara bahwa bentuk bimbingan anak-anak kelas tinggi dilaksanakan secara tidak lansung oleh orang tua. Hal ini dibuktikan dengan dengan hasil wawancara bahwa SN yang merupakan orang tua anak kelas 4 tidak melakukan pendampingan dari awal pembelajaran hingga akhir pembelajaran. SN hanya mengingatkan dan mengetahui kalau anaknya sudah bias belajar secara mandiri. Artinya orang tua melaksanakan bimbingan sesuai dengan kebutuhan anak serta membantu menyelesaikan permasalahan belajar anak. Pembimbingan oleh orang tua ini dilaksanakan dalam kegiatan seperti anak sulit memahami materi ajar dan anak menemukan tugas yang sulit dikerjakan anak.

Pendampingan kepada anak dalam belajar di rumah bisa berupa memeriksa tugas anak dan berkomunikasi dengan anak mengenai kesulitan belajarnya (Kusumaningrum et.al, 2020). Dikuatkan dengan hasil penelitian bahwa peran penting orangtua dalam mendampingi anak yakni agar aanak merasa tidak sendiri, sebagai motivator, fasilitator, serta tempat berdiskusi dan bertanya (Iftitah \& Anawaty, 2020).

Peran selanjutnya yakni orang tua sebagai jembatan antara anak dan guru. Peran tersebut meliputi penyalur informasi dan pembangun komunikasi antara guru dan anak. Meliputi mengumpulkan tugas-tugas dari guru bagi anak kelas rendah, menyampaikan berbagai informasi yang disampaikan guru, serta menyampaikan ulasan dari guru kepad anak. Sebagaimana bahwa peran orang tua dengan melakukan pendampingan mulai mengerjakan tugas-tugas hingga mengumpulkan tugas-tugas tersebut, juga membantu kesulitan belajar anak 
sehingga proses belajar akan menjadi positif (Nofianti, 2020). Hal ini juga senada dengan pendampingan belajar dengan membantu mengerjakan tugas, menjelaskan kepada anak, dan memberikan respon yang baik (Yulianingsih et.al, 2020).

Selain itu, orang tua juga memberikan fasilitas-fasilitas yang menunjang pembelajaran online. Fasilitas tersebut berupa handphone, kuota internet atau wifi, buku tulis, alat-alat tulis, serta beberapa kebutuhan lain yang relevan dengan kegiatan pembelajaran online serta yang memudahkan pembelajaran. Fasilitas pembelajaran yang disediakan orang tua berkaitan denan teknologi, informasi, dan komunikasi. Fasilitas tersebut berguna bagi anak agar bisa mengikuti pembelajaran dengan efektif. Sebagaimana penelitia bahwa peran orang tua sebagai pemenuh kebutuhan pembelajaran daring anak berupa smartphone dan jaringan internet (Selviana, 2020). Dikuatkan juga bahwa tua harus memfasilitasi kebutuhan anak untuk kegiatan belajarnya di rumah (Iftitah \& Anawaty, 2020).

Hasil tersebut kemudian didukung oleh perolehan angket tentang peran orang tua sebagai fasilitator berikut ini:

Tabel 2. Rekapitulasi data angket peran orang tua sebagai fasilitator

\begin{tabular}{ccc}
\hline Orang Tua & Total Skor & Kategori \\
\hline NN & 55 & Sangat baik \\
\hline ER & 60 & Sangat baik \\
\hline SN & 56 & Sangat baik \\
\hline HT & 50 & Sangat baik \\
\hline YW & 60 & Sangat baik \\
\hline AI & 49 & Sangat baik \\
\hline YS & 49 & Sangat baik \\
\hline
\end{tabular}

Berdasarkan perolehan angket tersebut dapat diketahui bahwa peran orang tua sebagai fasilitator dalam kategori sangat baik. Fasilitator dalam hal ini sebagai penyedia sarana dan prasarana dalam kegiatan pembelajaran, pendamping kegiatan pembelajaran online anak, mengontrol kegiatan pembelajaran online, mengetahui kesulitan belajar anak, membantu anak dalam menyelesaikan permasalahan, dan membantu anak dalam menyelesaikan tugas.

\section{Kendala Orang Tua Sebagai Fasilitator Pembelajaran Online}

Pelaksanaan pembelajaran online merupakan hal yang baru dirasakan oleh para orang tua. Hal ini menjadikan orang tua lebih intens dalam menjalankan peran dan tugasnya kepada anak. Orang tua memliki beberapa peran dalam hal ini peran sebagai fasilitator utama pada pembelajaran online. Sehingga dalam pelaksanaannya 
terdapat beberapa kendala yang dirasakan oleh orang tua. Berikut disampaikan hasil wawancara beberapa orang tua anak.

Hasil wawancara diketahui bahwa kendala yang dialami SN yakni anak yang cenderung malas belajar. Sehingga untuk mengatasi kendala tersebut SN membatasi penggunaan Handphone yang menyebabkan anak mau kembali belajar lagi. Sedangkan kendala yang dialamai oleh ER juga anak yang juga cenderung bosan belajar. Maka sebagai upaya ER untuk mengatasi hal tersebut yaitu dengan memberikan nasihat dan motivasi serta memberikan kesempatan anak untuk menonton satu video untuk menumbuhkan semangat belajar anak.

Berdasarkan hasil wawancara kepada orang tua anak sebagaimana di atas, kemudian disajikan dalam bentuk tabel berikut secara lebih jelas dan lengkap.

Tabel 3. Rekapitulasi data peran orang tua sebagai fasilitator

\begin{tabular}{cl}
\hline Orang Tua & \multicolumn{1}{c}{ Kendala } \\
\hline NN & $\begin{array}{l}\text { Materi yang cukup sulit dan keterbatasan pemahaman } \\
\text { orang tua }\end{array}$ \\
\hline ER & Motivasi anak yang kurang \\
\hline SN & $\begin{array}{l}\text { Anak yang cenderung semaunya sendiri dan motivasi } \\
\text { belajar yang menurun }\end{array}$ \\
\hline HT & Kurangnya pemahaman anak dan orang tua pada materi \\
\hline YW & Penurunan motivisai belajar anak \\
\hline AI & $\begin{array}{l}\text { Anak yang cenderung ingin main handphone terus } \\
\text { menerus }\end{array}$ \\
\hline YS & $\begin{array}{l}\text { Keterbatasan pemahaman orang tua mengenai materi } \\
\text { pembelajaran }\end{array}$ \\
\hline
\end{tabular}

Beberapa kendala yang dirasakan oleh orang tua meliputi materi yang kurang dikuasai oleh orang tua dan motivasi anak yang cenderung menurun. Kendala pertama yakni penguasaan materi yang kurang, hal ini menjadi kendala bagi orang tua. Sebab pemahaman materi yang luas oleh orang tua sangat membantu pelaksanaan pembelajaran online. Orang tua sebagai guru juga pembimbing utama anak sehingga memerlukan keluasan pengetahuan. Kurangnya pemahaman materi orang tua menyebabkan tidak maksimalnya pendidikan di rumah (Irma et.al, 2019). Sebagai bentuk usaha mengurangi kendala tersebut, orang tua berusaha mencari sumber-sumber belajar yang lain. Berupa mencari melalui google, bertanya kepada orang-orang yang dianggap mampu. Upaya pendampingan dapat dilakukan melalui berbagai macam cara seperti di antaranya membantu ketika ada kesulitan (Kurniati et al., 2020). Hal ini dikuatkan juga oleh bahwa peran orang tua dalam pembelajaran pada masa pandemi yakni dengan mendukung 
pembelajaran anak-anak mereka serta mengembangkan pengetahuan yang relevan (Panaoura, 2021) .

Kendala yang lainnya berupa motivasi anak yang menurun. Hal ini terjadi karena pembelajaran online dilakukan di rumah dan tidak bersama teman-teman yang lain. Sehingga anak-anak menjadi lebih cepat bosan. Sebagai upaya untuk mengatasi hal tersebut maka orang tua memberikan beberapa motivasi kepada anak, penjelasan kepada anak tentang pentingnya belajar, juga kesepakatan mengenai waktu bermain dan belajar. Orang tua mengajarkan dan membangun regulasi diri dan mengembangkan perilaku guna memiliki kemampuan mengatur dan merencanakan proses belaja (Wardani, A., \& Ayriza, 2020). Hal ini didukung oleh hasil penelitian lain bahwa orang tua yang memiliki semangat tinggi untuk motivasi belajar dan mengembangkan kemampuan belajar anak akan membawa dampak yang baik bagi anak (Hayati, 2020).

\section{SIMPULAN}

Berdasarkan penjelasan di atas dapat diketahui bahwa peran orang tua sebagai fasilitator dalam pembelajaran online meliputi orang tua melakukan pendampingan kepada anak, orang tua sebagai jembatan antara anak dan guru, serta orang tua sebagai penyedia fasilitas yang menunjang pembelajaran online. Pelaksanaan pembelajaran online yang merupakan hal baru bagi orang tua menimbulkan beberapa kendala diantaranya keluasan pengetahuan orang tua yang kurang serta motivasi anak yang cenderung menurun. Untuk itu perlunya orang tua melakukan pendalaman materi berupa mencari beberapa sumber-sumber lain, juga mengondisikan kegiatan belajar dari rumah menjadi lebih menyenangkan dengan beberapa motivasi yang dapat menumbuhkan semangat anak. Sehingga pembelajaran online menjadi lebih efektif.

\section{UCAPAN TERIMA KASIH}

Ucapan terima kasih ditujukan untuk progam studi Pendidikan Guru Sekolah Dasar Fakultas Kegururan dan Ilmu Pendidikan Universitas Muria Kudus. Tak lupa ucapan terima kasih juga kepada kedua orang tua, beserta teman-teman yang selalu memberikan dukungan dalam penyelesaian artikel ini. 


\section{DAFTAR PUSTAKA}

Astini, N. K. S. (2020). Pemanfaatan teknologi informasi dalam pembelajaran tingkat sekolah dasar pada masa pandemi Covid-19. Jurnal Lampuhyang, 11(2), 13-25.

Dewi, W. A. F. (2020). Dampak Covid-19 terhadap implementasi pembelajaran daring di Sekolah Dasar. Edukatif: Jurnal Ilmu Pendidikan, 2(1), 55-61. https://doi.org/10.31004/edukatif.v2i1.89

Hayati, A. S. (2020). Peran orang tua dalam meningkatkan motivasi belajar anak dengan sistem daring pada masa pandemi di Desa Depokrejo, Kebumen. Tasyri': Jurnal Tarbiyah-Syari'ah Islamiyah, 27(2), 23-32.

Iftitah, S. L., \& Anawaty, M. F. (2020). Peran orang tua dalam mendampingi anak di rumah selama pandemi Covid-19. JCE (Journal of Childhood Education), 4(2), 71-81. https://doi.org/10.30736/jce.v4i2.256

Irma, C. N., Nisa, K., \& Sururiyah, S. K. (2019). Keterlibatan orang tua dalam pendidikan anak usia dini di TK Masyithoh 1 Purworejo. Jurnal Obsesi: Jurnal Pendidikan Anak Usia Dini, 3(1), 214-224. https://doi.org/10.31004/obsesi.v3i1.152

Kholiq, A., Daniarti, U. A., \& Harisuddin. (2017). Peran orang tua dalam meningkatkan prestasi belajar kelas VIII SMPK Mater Boni Consili Ohe Kecamatan Hewokloang Kabupaten Sikka. Jurnal Oikos, 1(1), 1-13.

Khurriyati, Y., Setiawan, F., \& Mirnawati, L. B. (2021). Dampak pembelajaran daring terhadap hasil belajar siswa MI Muhammadiyah 5 Surabaya. Jurnal Ilmiah Pendidikan Dasar, 8(1), 91-104. https://doi.org/10.30659/pendas.8.1.91-104

Kurniati, E., Alfaeni, D. K. N., \& Andriani, F. (2020). Analisis peran orang tua dalam mendampingi anak di masa pandemi Covid-19. Jurnal Obsesi: Jurnal Pendidikan Anak Usia Dini, 5(1), 241-256. https://doi.org/10.31004/obsesi.v5i1.541

Kusumaningrum, B., Kuncoro, K. S., Arigiyati, T. A., \& Trisniawati. (2020). Pendampingan Orangtua Dalam Pembelajaran Daring Di Sekolah Dasar. INVENTA: Jurnal Pendidikan Guru Sekolah Dasar, 4(2), 142-150. https://doi.org/10.36456/inventa.4.2.a2607

Lilawati, A. (2020). Peran orang tua dalam mendukung kegiatan pembelajaran di rumah pada masa pandemi. Jurnal Obsesi, 5(1), 549-558. https://doi.org/10.31004/obsesi.v5i1.630

Nofianti, R. (2020). Peran orangtua dalam pendampingan pembelajaran daring anak usia dini di masa pandemic Covid 19 di TK Islam Ibnu Qoyyim. Jurnal Abdi IImu, 13(2), 19-30.

Panaoura, R. (2021). Parental involvement in children's mathematics learning before and during the period of the Covid-19. Social Education Research, 2(1), 65-74.

Prasetyo, F. A. . (2018). Pendampingan Orang Tua dalam Proses Belajar Anak. Universitas Sanata Dharma Yogyakarta.

Saputri, A. E. (2017). Pendampingan Anak dalam Keluarga di TK Pertiwi Kebasen Kabupaten Banyumas. Universitas Negeri Yogyakarta.

Selviana, E. (2020). Peran orang tua dalam pembelajaran daring siswa kelas IV pada pembelajaran tematik terhadap pencapaian KKM di MI Ma'arif 2 Wadas Kecamatan Kandangan Kabupaten Temanggung Tahun Ajaran 2019/2020. IAIN Salatiga.

Sholeh, M., Murtono, \& Masfuah, S. (2021). Efektivitas pembelajaran Google Classroom dalam meningkatkan kemampuan literasi membaca siswa. Jurnal Educatio, 7(1), 134-140.

Sugiyono. (2017). Metode Penelitian Pendidikan Pendekatan Kuantitatif, Kualitatif, dan $R \& D$. Alfabeta. 
Susanto, A. (2013). Teori Belajar \& Pembelajaran di Sekolah Dasar. Prenadamedia Group.

Syafa'ati, J. S. N., Sucipto, \& Roysa, M. (2021). Analisis prestasi belajar siswa pada pembelajaran daring di masa pandemi Covid-19. Jurnal Educatio, 7(1), 122128.

Umar, M. (2015). Peranan orang tua dalam peningkatan prestasi belajar anak. Jurnal Ilmiah Edukasi, 1(1), 20-28.

Wardani, A., \& Ayriza, Y. (2020). Analisis kendala orang tua dalam mendampingi anak belajar di rumah pada masa pandemi Covid-19. Jurnal Obsesi: Jurnal Pendidikan Anak Usia Dini, 5(1), 772-782. https://doi.org/10.31004/obsesi.v5i1.705

Wardhani, T. Z. ., \& Krisnani, H. (2020). Optimalisasi peran pengawasan orang tua dalam pelaksanaan sekolah online di masa pandemi Covid-19. Prosiding Penelitian \& Pengabdian Kepada Masyarakat, 48. https://doi.org/https://doi.org/10.24198/jppm.v7i1.28256

Warsito. (2012). Peningkatan Motivasi dan Hasil Belajar Metematika Melalui Pendekatan Kontruktivisme dengan Mengoptimalkan Media Information and Communication Technologies (ICT). Universitas Muhammadiyah Surakarta.

Winarno, \& Setiawan, J. (2013). Penerapan sistem e-learning pada komunitas pendidikan sekolah rumah Home Schooling. Jurnal Ultima Infosys, 4(1), 45-51.

Yulianingsih, W., Suhanadji, S., Nugroho, R., \& Mustakim, M. (2020). Keterlibatan Orangtua dalam Pendampingan Belajar Anak selama Masa Pandemi Covid-19. Jurnal Obsesi: Jurnal Pendidikan Anak Usia Dini, 5(2), 1138-1150.

Conflict of Interest Statement: The authors declare that the research was conducted in the absence of any commercial or financial relationships that could be constructed as a potential conflict of interest. 